\title{
Pollen morphology in tribe Dicomeae Panero and Funk (Asteraceae)
}

\author{
A. Pereira Coutinho $\cdot$ R. Almeida da Silva $\cdot$ \\ D. Sá da Bandeira $\cdot S$. Ortiz
}

Received: 27 January 2012/ Accepted: 16 July 2012/Published online: 17 August 2012

(C) Springer-Verlag 2012

\begin{abstract}
To better understand the taxonomy and phylogeny of the Dicomeae (Asteraceae) the pollen morphology of seven genera including 15 species of that tribe and six genera with seven species belonging to five related tribes was studied by use of light and scanning electron microscopy. The quantitative data were analysed by use of principal-components analysis (PCA). The exine ultrastructure of Erythrocephalum longifolium and Pleiotaxis rugosa was also studied by use of transmission electron microscopy. Three pollen types were distinguishable from the apertural, columellar, and spinular morphology and inter-spinular sculpture. A dichotomous key to these pollen types is proposed. The existence of the Dicomeae as an independent tribe and its subdivision in two subtribes (Dicominae and Pleiotaxinae) are supported by this study, which also suggests the Oldenburgieae and the Tarchonantheae are the closest tribes to Dicomeae.
\end{abstract}

Keywords Dicomeae $\cdot$ Pollen morphology $\cdot$ Asteraceae · Taxonomy

\footnotetext{
A. Pereira Coutinho $(\bowtie) \cdot D$. Sá da Bandeira Department of Life Sciences, Faculty of Sciences e-mail: cafe@ bot.uc.pt

R. Almeida da Silva

Department of Biology and CIBIO, Faculty of Sciences,

University of Porto, Porto, Portugal

S. Ortiz

Department of Botany, Faculty of Pharmacy,

University of Santiago de Compostela,

Santiago de Compostela, Spain
} and Technology, University of Coimbra, Coimbra, Portugal

\section{Introduction}

The tribe Dicomeae was firstly described by Panero and Funk (2002), and includes eight genera and 95 species of perennial herbs, shrubs, or small trees, mainly with an African and Malagasy distribution, though one species occurs in the Arabian Peninsula and another in India and Pakistan (Ortiz 2000; Ortiz et al. 2009). This taxon comprises most of the African genera previously included in the Mutisieae by authors such as Hoffmann (1890), Jeffrey (1967), Cabrera (1977) and Bremer (1994).

Morphological phylogenetic analysis by Ortiz (2000), ITS (rDNA) and $n d h F$ (cpDNA) analysis by Ortiz et al. (2009), and $n d h F+$ trnL-F (cpDNA) analysis by Ortiz et al. (unpublished) revealed that the genera Cloiselia, Dicoma, "Dicomopsis" (unpublished), Macledium, and Pasaccardoa belong to a monophyletic group (Dicoma s. 1.) and seem closely related to each other. The other three genera (Erythrocephalum, Gladiopappus, and Pleiotaxis) are quite dissimilar from the taxa of that clade. No sequence data of Gladiopappus are yet available but Erythrocephalum and Pleiotaxis constitute a separate monophyletic group and a distinct subtribe (Pleiotaxinae-Ortiz et al. unpublished) or even a new tribe of Asteraceae (Ortiz et al. 2009). According to Ortiz et al. (unpublished), the other genera of Dicomeae belong to subtribe Dicominae.

According to many authors (Skvarla and Larson 1965; Skvarla et al. 1977, 2005; Bolick 1978, 1991; Zavada and De Villiers 2000; Tellería and Katinas 2005; Pereira Coutinho and Dinis 2007; Wortley et al. 2008) a knowledge of pollen morphology is important to understanding the taxonomy, phylogeny, and ecology of the Asteraceae. For this reason we investigated, by use of light and scanning electron microscopy, pollen morphology in seven genera (Cloiselia, Dicoma, "Dicomopsis", Erythrocephalum, Macledium, 
Pasaccardoa, and Pleiotaxis) and 15 species (Cloiselia carbonaria S. Moore, C. olaeifolia (Humbert) S. Ortiz, Dicoma anomala Sond., D. tomentosa Cass., "Dicomopsis" welwitschii, Erythrocephalum longifolium Benth. ex Oliv. (=E. zambesianum Oliv. \& Hiern.), E. marginatum (O. Hoffm.) S. Ortiz \& A. P. Cout., E. microcephalum Dandy, Macledium latifolium (DC.) S. Ortiz, M. sessiliflorum (Harv.) S. Ortiz, M. spinosum (Harv.) S. Ortiz, Pasaccardoa baumii O. Hoffm., P. jeffreyi Wild, Pleiotaxis rugosa O. Hoffm., P. subpaniculata Chiov.)) of Dicomeae. The specimens studied are listed in "Appendix". The exine of Erythrocephalum longifolium and Pleiotaxis rugosa was also studied by use of transmission electron microscopy (TEM). These taxa were chosen because they represent all the clades of that tribe in the cladograms of Ortiz (2000) and Ortiz et al. (2009). To compare the pollen morphology of the Dicomeae with that of related tribes, the pollen grains of some Barnadesieae (Barnadesioideae-Chuquiraga jussieui J. F. Gmel. and C. oppositifolia D. Don), Oldenburgieae (Oldenburgia paradoxa Less.), Stifftieae (Gongylolepis sp.), Tarchonantheae (Brachylaena discolor DC. and Tarchonanthus camphoratus L.), and Wunderlichieae (Stenopadus sp.) were also studied, as outgroups, by use of scanning electron microscopy (SEM) and light microscopy (LM).

The palynology of those outgroup taxa was studied by Parra and Marticorena (1972, Chuquiraga-LM), Urtubey and Tellería (1998, Chuquiraga-LM, SEM), Tellería (2008, Gongylolepis, Stenopadus-LM, SEM), and Ubiergo et al. (2009, Gongylolepis-LM, SEM). The pollen morphology of the Dicomeae was studied by use of LM by Stix (1960) and Wodehouse (1929), by use of SEM by Hansen (1990), by use of SEM and LM by Perveen (1999), by use of SEM and TEM by Blackmore et al. (2010), and by use of SEM, TEM and LM by Ortiz and Pereira Coutinho (2001). Despite these contributions, however, the palynology of this tribe is still insufficiently known. Therefore we decided to contribute to a better understanding of the taxonomy of this tribe by studying the pollen morphology of a significant sample of its taxa.

\section{Materials and methods}

Pollen grains were collected from herbarium vouchers held at the British Museum of Natural History (BM), Royal Botanic Gardens of Kew (K), South African National Botanical Institute (PRE), Swedish Museum of Natural History (S), Royal Botanic Garden of Madrid (MA), and University of Coimbra (COI) and then acetolysed in accordance with Erdtman (1960). Specimens examined and voucher data are given at the end of the paper. The terminology used for description pollen follows Punt et al. (2007), Blackmore et al. (2009), and Hesse et al. (2009).
Light microscopy

Pollen grains were mounted in silicone oil and observed with a Motic BA 310 using a Stenothe $\times 100$ oil-immersion objective. Each of the characteristics length of polar axis $(P)$ and length of equatorial diameter $(E)$, both in meridian optical section (mos), the number of spines/ $100 \mu^{2}$ of the mesocolpium, spine length and width at the base (except for Chuquiraga and Stenopadus), width of the endoaperture, and exine thickness at the poles was measured for 30 pollen grains. The ratios $P / E$, spine height/ spine width, and E/exine thickness were then established.

\section{Scanning electron microscopy}

After acetolysis, pollen grains were treated with ultrasound $(35 \mathrm{kc} / \mathrm{s}, 1 \mathrm{~h})$ to increase the number of fractures, and dehydrated in a graded acetone series (70-100\%). They were then mounted on aluminium stubs and sputter coated with a 30-nm layer of gold-palladium before examination with a Jeol JSM-5400 at $10 \mathrm{kV}$. By using micrographs of the fractured grains we measured the thicknesses of the endexine, foot layer, internal tectum, and tectum, the height of the supporting and outer columellae, and the diameter of both the spinular and inter-spinular perforations. We also measured the spine length and spine width at the base of the pollen grains of Chuquiraga and Stenopadus.

\section{Transmission electron microscopy}

Pollen grains of Erythrocephalum longifolium and Pleiotaxis rugosa were fixed in osmium tetroxide and embedded in Spurr's resin as described elsewhere (Pereira Coutinho and Dinis 2007). Thin sections were cut with an LKB Ultrotome Nova ultramicrotome equipped with a diamond knife, conventionally stained with uranyl acetate and lead citrate, and observed with a Jeol JEM-100 SX at $80 \mathrm{kV}$. By using micrographs of the exine of those species, we measured the thicknesses of the endexine, foot layer, internal tectum, and tectum, the height and width of the supporting and outer columellae, and the diameter of both the spinular and inter-spinular perforations.

\section{Data treatment and statistical analysis}

The arithmetic mean, standard deviation, maximum, and minimum were calculated for all the measured pollen characters and ratios. Indirect gradient analysis was used to identify specimen assemblages on the basis of several morphological and anatomical quantitative traits. Preliminary detrended correspondence analysis (DCA) of the data-set, with detrending by segments and non-linear rescaling (Legendre and Legendre 1998), provided an 
estimate of the underlying gradient length. Because the gradient length obtained was short (less than approx. 2.5 $\mathrm{SD})$, the assemblage variation is within a relatively narrow range, and the linear approach of principal-components analysis (PCA) is appropriate. Original data were log transformed before analysis of the nature of the selected traits (i.e. the magnitude of the respective values). All indirect gradient analyses were performed in Canoco 4.5 for Windows.

\section{Results}

General description of the pollen morphology of Dicomeae

Pollen radially symmetrical and isopolar, suboblate or prolate, $P / E=0.87-2.00(1.12 \pm 0.12)$, subcircular or elliptical in mos (Fig. 1g), triangular-circular to circular in equatorial optical section (eos). $P=33.70-75.00$ $(50.60 \pm 8.30) \mu \mathrm{m}, E=21.00-68.00(46.00 \pm 8.00) \mu \mathrm{m}$. $E$ (average)/exine thickness at the poles (average) $=6.13$. Trizonocolporate, with apertures constituted by an ecto, a meso, and an endo-aperture (Figs. 1a-d, f, i, j, 2a, e, 3a, b); ectoapertures-colpi elongated, acute at the ends (Figs. 1c, f, 2d, f, g); mesoapertures lolongate (Fig. 1d, i, j) or lalongate (Fig. 1a-c, f), elliptical, endoapertures lalongate, generally spindle-shaped and acute at the ends (Fig. 1a-c, $\mathrm{f}, \mathrm{i})$, sometimes narrowed at the centre and semi-circular at the ends ("butterfly"-shaped, Fig. 1d), width $=5.90$ $23.00(17.30 \pm 5.90) \mu \mathrm{m}$; colpal membranes psilate or scabrate (Figs. 2a, d, 3a, b); costae conspicuous (Fig. 1g). Exine tectate, echinate, acaveate (Figs. 1h, 2b, c, i, 3e, f, $4 \mathrm{a}, \mathrm{b}$ ), with an anthemoid structure (Fig. 4a, b); thickness at the poles $=3.90-11.00(7.50 \pm 1.40) \mu \mathrm{m}$. Tectum perforate (Figs. 2, 3, 4) $0.15-0.40 \mu \mathrm{m}$ thick; outer columellae smaller than the supporting columellae (Figs. 2c, 3f, 4a, b) $0.15-0.90 \mu \mathrm{m} \times 0.12-0.35 \mu \mathrm{m}, \quad$ length/width $=$ 1.30-3.70; internal tectum more or less fragmented (Fig. 4a, b), $0.20-1.20 \mu \mathrm{m}$ thick; supporting columellae very variable in dimensions and shape, $1.10-4.00 \mu \mathrm{m} \times 0.16-1.30 \mu \mathrm{m}$, length/width $=1.00-21.40$, nearly straight (Figs. 1a, g, 2b, c, i) or more or less curved (Figs. 3e, f, 4a), and more or less ramified and branched (Figs. 2, 3, 4); foot layer $0.15-1.70 \mu \mathrm{m}$ thick; endexine generally thinner than the foot layer (Figs. 2b, i, 4a), 0.08-1.50 $\mu$ thick. Spines conic with straight (Figs. 2c, 3a, d) or concave (Figs. 1b, $2 \mathrm{~d}$, e, g, 4b) sides, attenuate or contracted in an acute (Figs. 1b, 3d), acuminate (Fig. 3g), or obtuse (Fig. 2d) apex, spinular columellae longer than the supporting columellae (Fig. 4b), apex with a sub-apical cavity (Fig. 4b); length $=0.90-8.23(2.88 \pm 0.90) \mu \mathrm{m}$, width at the base $=1.90-11.54(4.79 \pm 1.78) \mu \mathrm{m}$, length/width at the base $=0.29-1.38(0.61 \pm 0.17) \mu \mathrm{m}$, number $/ 100 \mu \mathrm{m}^{2}$ in the mesocolpium $=1-5(2.50 \pm 0.90)$; spinular perforations $=0.10-1.14 \mu \mathrm{m}$. Inter-spinular sculpture perforate (Figs. 2d, e, 3a, b) or microreticulate (Figs. 2f, g, 3c-f), sometimes rugulate-perforate (Fig. $2 \mathrm{~h}$ ), at least near the colpi margines; inter-spinular perforations $=0.09-0.70 \mu \mathrm{m}$.

Pollen types

Dicoma anomala (incl. Cloiselia carbonaria, C. olaeifolia, D. anomala, D. tomentosa, "Dicomopsis" welwitschii, "D." baumii, Pasaccardoa jeffreyi, Macledium latifolium, M. sessiliflorum and M. spinosum)

Pollen grains oblate-spheroidal to prolate, $P / E=0.95-$ $2.00(1.17 \pm 0.10)$, subcircular to elliptical in mos, triangular-circular or circular in eos. $P=34.00-75.00$ $(51.70 \pm 8.32) \mu \mathrm{m} ; E=20.50-65.00(45.00 \pm 7.90) \mu \mathrm{m}$. Mesoapertures lalongate (Fig. 1b, c, f), elliptic-shaped; endoapertures spindle-shaped, width of the endoapertures $=11.80-29.00(18.58 \pm 4.16) \mu \mathrm{m}$. Supporting columellae relatively thick and straight, $1.30-2.90 \mu \mathrm{m} \times$ $0.60-1.50$, length/width $=1.00-4.60$, densely distributed; exine thickness at the poles $=5.00-11.00(7.60 \pm 1.30)$ $\mu \mathrm{m}$. Spines with concave or straight sides, attenuated or rarely contracted in an acute apex, length $=0.90-3.70$ $(2.34 \pm 0.70) \mu \mathrm{m}$, width at the base $=2.00-7.00(4.42 \pm$ 1.35) $\mu \mathrm{m}$, length/width at the base $=0.29-0.90(0.54 \pm$ $0.12)$, number of spines $/ 100 \mu \mathrm{m}^{2}=1-5 \quad(2.34 \pm 0.70)$, inter-spinular sculpture perforate, sometimes rugulate-perforate at least near the apertures.

\section{Erythrocephalum longifolium (incl. E. longifolium, E. marginatum and E. microcephalum)}

Pollen grains suboblate to prolate-spheroidal, $P / E=$ 0.87-1.07 (0.97 \pm 0.08$)$, subcircular to elliptical in mos., triangular-circular or circular in eos. $P=33.50-50.20$ $(42.20 \pm 3.79) \mu \mathrm{m} ; E=36.00-51.70(43.50 \pm 4.26) \mu \mathrm{m}$. Mesoapertures lolongate (Fig. 1d), elliptic-shaped; endoapertures narrowed in the centre and semi-circular in the ends ("butterfly-shaped"; Fig. 1d), width of the endoapertures $=5.90-20.40 \quad(11.90 \pm 3.40) \quad \mu \mathrm{m}$. Supporting columellae thin, loosely distributed, curved, $2.20-4.00 \mu \mathrm{m} \times$ $0.15-0.20 \mu \mathrm{m}$, length/width $=10-25$; exine thickness at the poles $=3.90-9.40(5.90 \pm 1.10) \mu \mathrm{m}$. Spines with concave sides, attenuated in an acuminate apex, length $=$ $2.70-8.20(5.07 \pm 1.53) \mu \mathrm{m}$, width at the base $=3.10$ $11.50(7.00 \pm 2.40) \mu \mathrm{m}$, length/width at the base $=0.55-1.37$ $(0.75 \pm 0.14)$, number of spines $/ 100 \mu \mathrm{m}^{2}=1-3(1.73 \pm$ $0.64)$, inter-spinular sculpture microreticulate. 

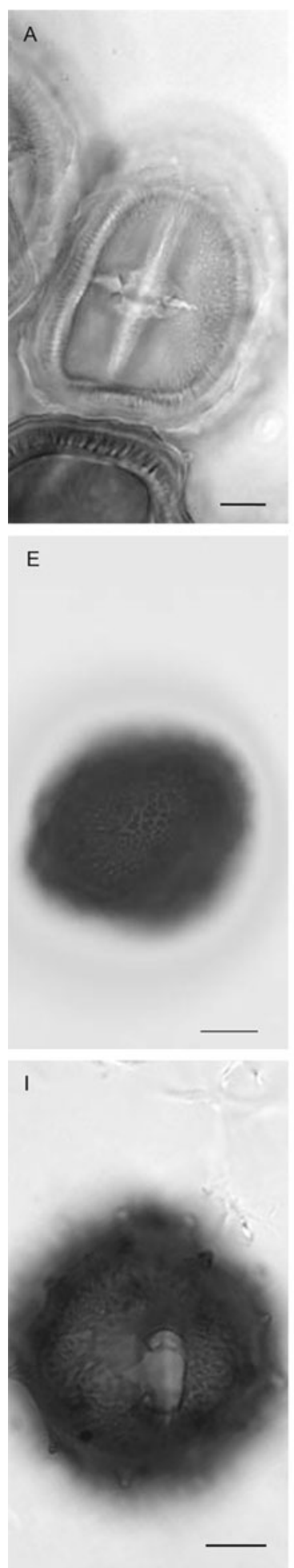

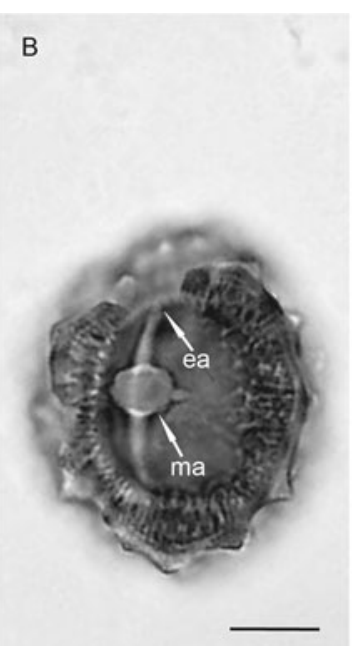

\section{$\mathrm{F}$}

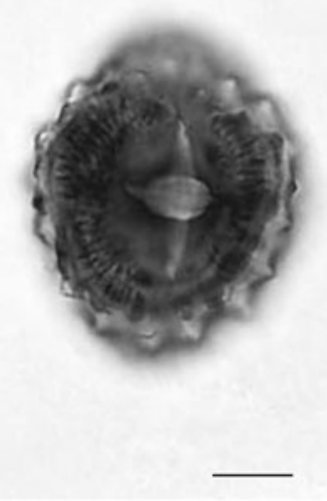

$J$

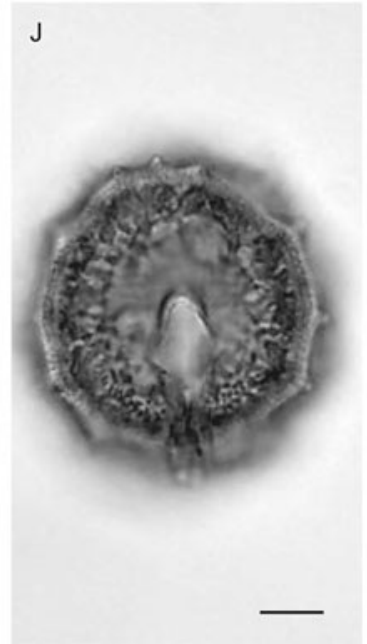

Fig. 1 LM micrographs. a Cloiselia carbonaria, equatorial superficial view, showing an aperture. b Dicoma anomala, equatorial superficial view, showing an aperture. c "Dicomopsis" welwitschii, equatorial superficial view, showing an aperture. d Erythrocephalum longifolium, equatorial superficial view, showing an aperture. e Macledium sessiliflorum, equatorial superficial view of a mesocolpium. f Pasaccardoa baumii, equatorial superficial view of a mesocolpium. g $P$. jeffreyi, meridional optical section. h Pleiotaxis

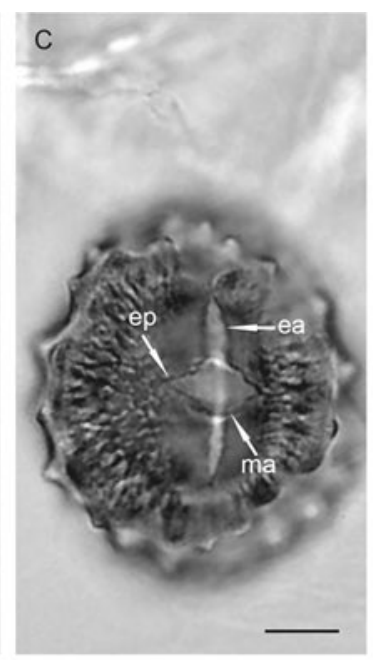

D

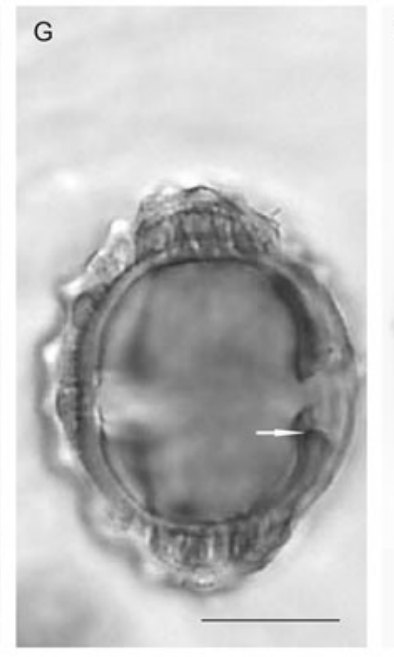

H
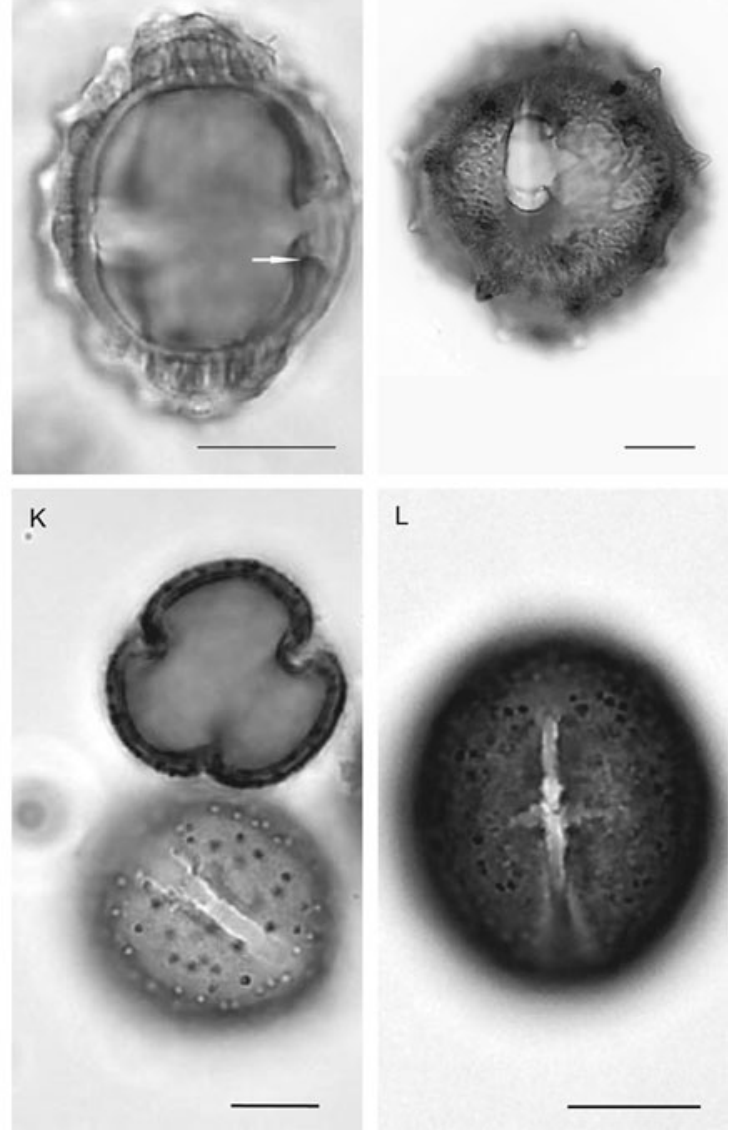

$\mathrm{L}$

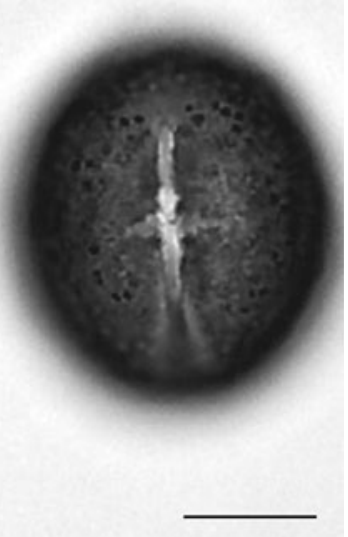

rugosa, equatorial superficial view, showing an aperture. i $P$. rugosa, equatorial superficial view, showing an aperture. $\mathbf{j} P$. subpaniculata, equatorial superficial view, showing an aperture. k Brachylaena rotundata, equatorial optical section and equatorial superficial view, showing an aperture, of two pollen grains. I Tarchonanthus camphoratus equatorial superficial view, showing an aperture. Arrow costae, $e a$ ectoaperture, $e p$ endoaperture, $m a$ mesoaperture. a-l bars $10 \mu \mathrm{m}$ 

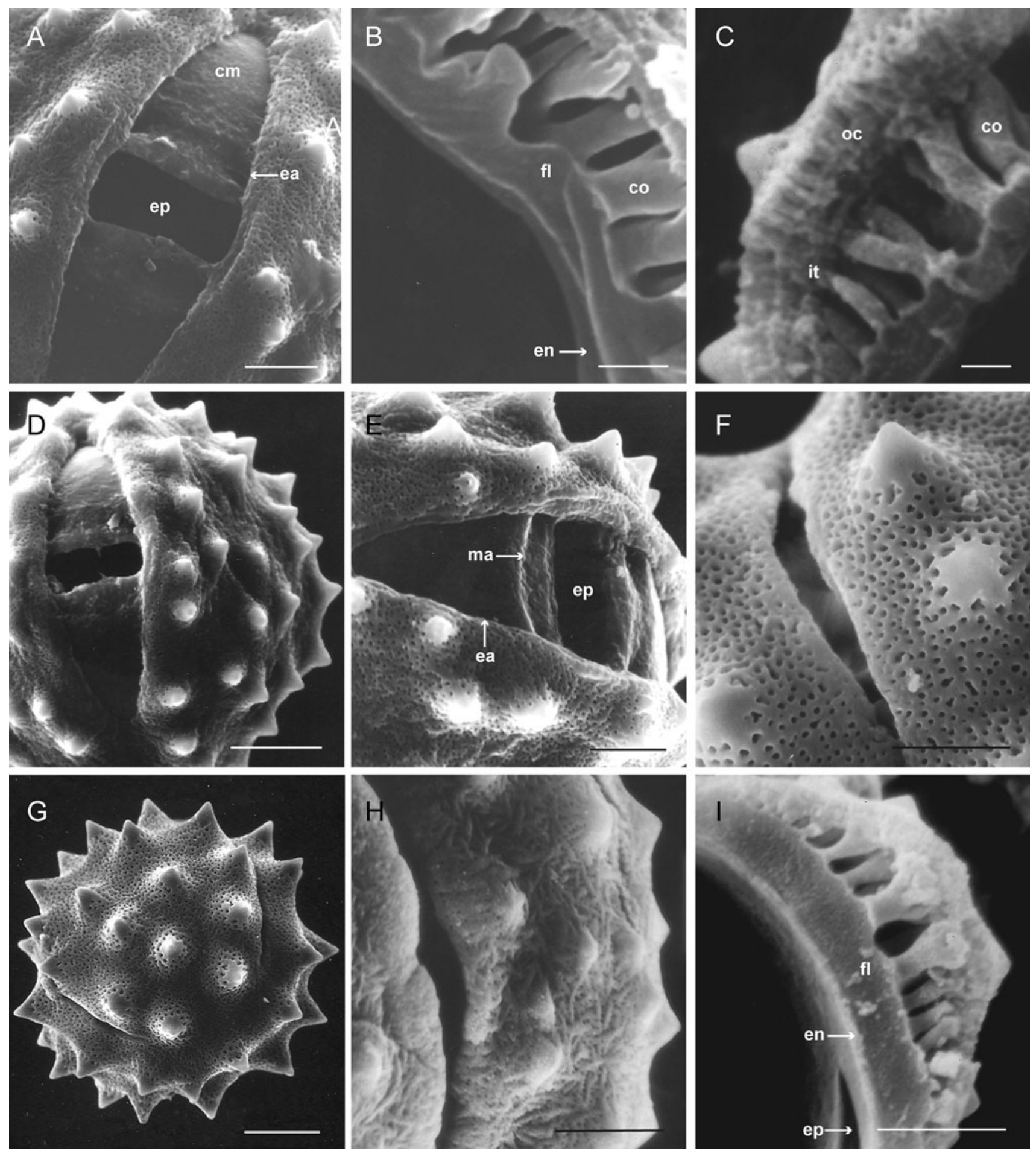

Fig. 2 SEM micrographs. Cloiselia carbonaria. a Equatorial view of an aperture. b Detail of a fractured exine. c C. olaeifolia, detail of a fractured exine. d Dicoma anomala, general equatorial view. e "Dicomopsis" welwitschii, equatorial view of an aperture. f Erythrocephalum longifolium, equatorial view of an aperture. g E. marginatum, general view. h Macledium latifolium, equatorial view of an aperture. i $M$. spinosum, detail of a fractured exine. $\mathrm{cm}$ colpus membrane, co supporting columellae, ea ectoaperture, en endexine, $e p$ endoaperture, $f$ foot layer, it internal tectum, ma mesoaperture, $o c$ outer columellae. a, e, f, h, i bars $5 \mu \mathrm{m} ; \mathbf{b}, \mathbf{c}$ bars $1 \mu \mathrm{m} ; \mathbf{d}, \mathbf{g}$ bars $10 \mu \mathrm{m}$ 

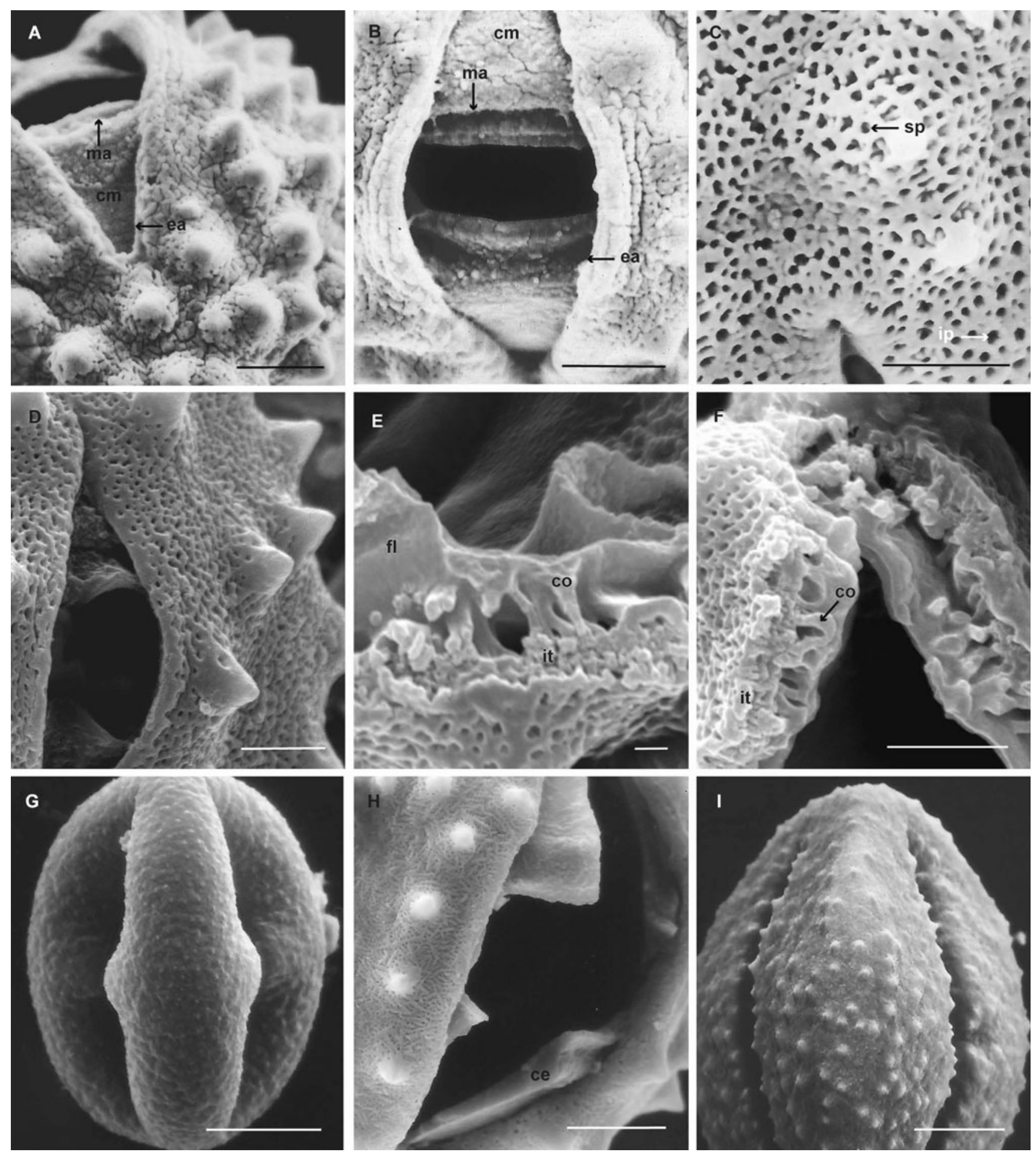

Fig. 3 SEM micrographs. Pasaccardoa baumii. a Polar view of the apocolpium and an aperture. b Equatorial view with an aperture. Pleiotaxis rugosa. c Polar view of the apocolpium and the apex of an aperture. d Equatorial view with an aperture. e, f $P$. subpaniculata, fractured exines. g Chuquiraga jussieui, equatorial view of a mesocolpius. h Gongylolepis sp. equatorial view with a fractured

aperture. i Stenopadus sp., equatorial view of a mesocolpius. ce costae, $\mathrm{cm}$ colpus membrane, co supporting columellae, ea ectoaperture, $e p$ endoaperture, $f l$ foot layer, it internal tectum, $m a$ mesoaperture, $o c$ outer columellae, $s p$ spine perforation. a-d, f bars $5 \mu \mathrm{m}$; e bar $1 \mu \mathrm{m} ; \mathbf{g}-\mathbf{i}$ bars $10 \mu \mathrm{m}$ 


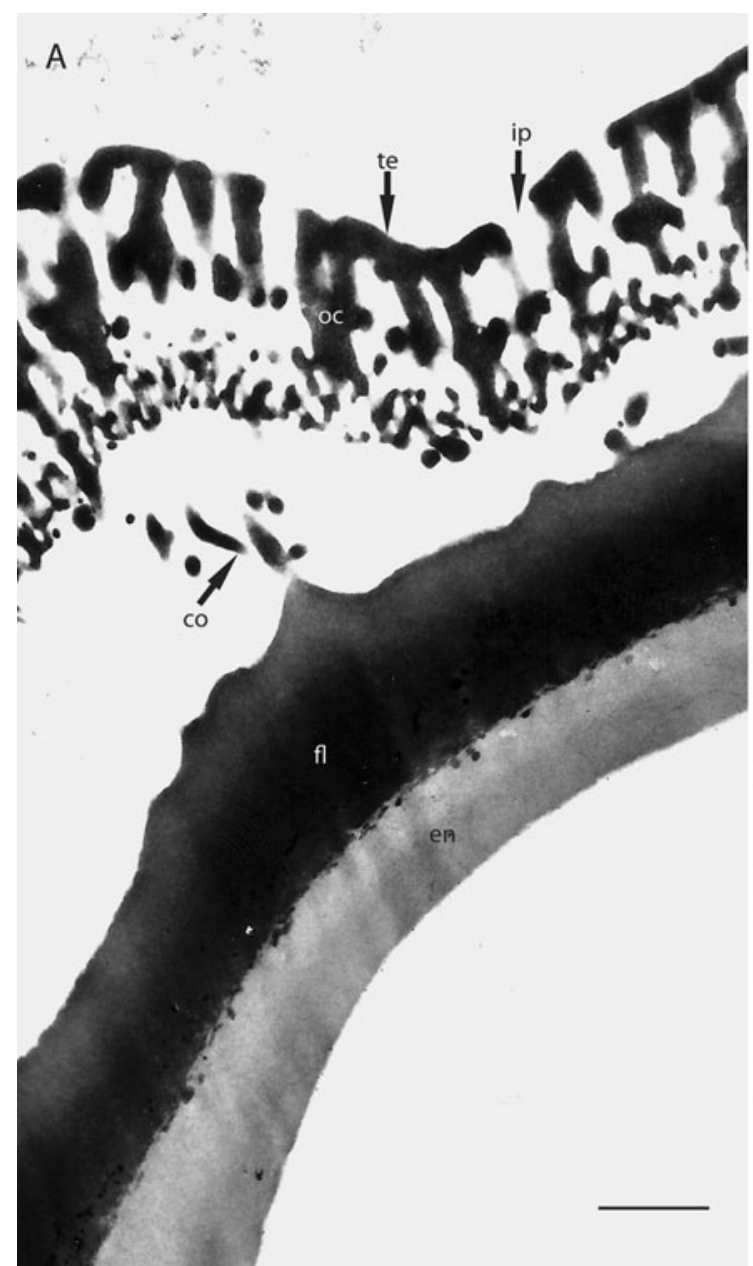

Fig. 4 TEM micrographs. Sections of the exine a Erythrocephalum longifolium. b Pleiotaxis rugosa. co supporting columellae, en endexine, $f l$ foot layer, $o c$ outer columellae, ip inter-spinular

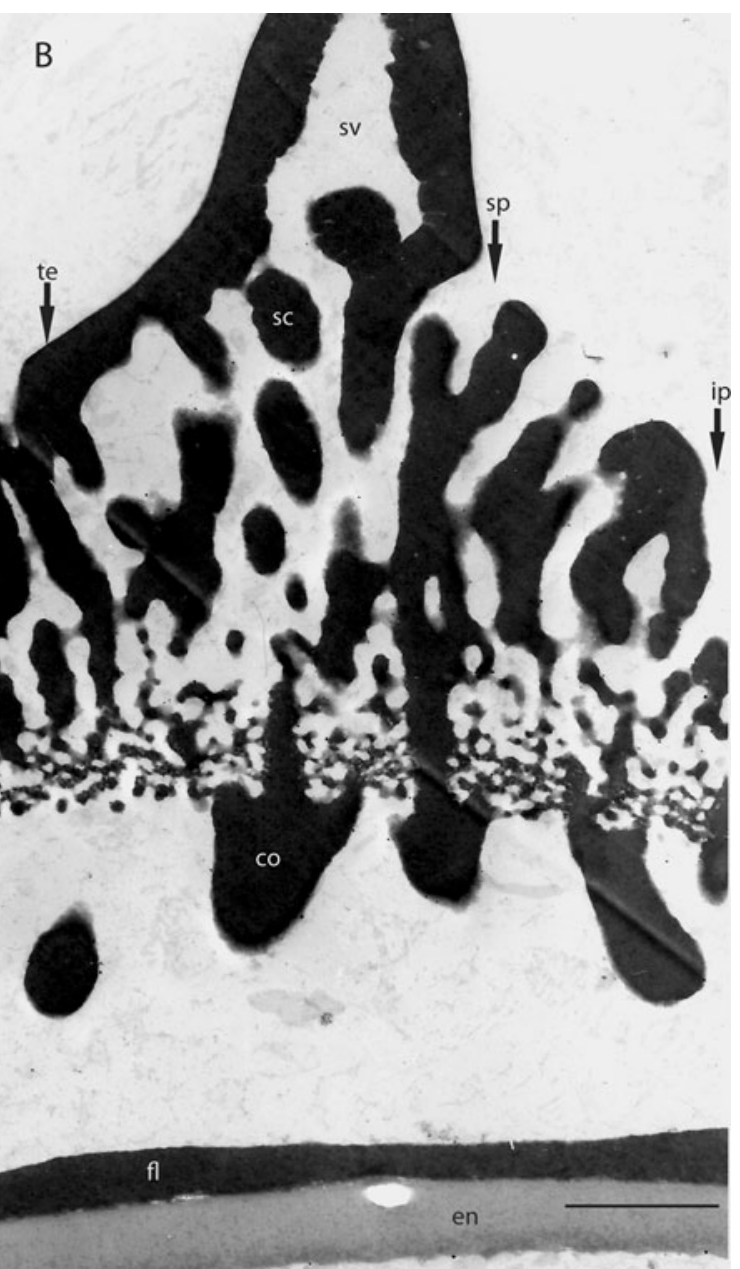

perforations, it internal tectum, $s c$ spinular columellae, $s p$ spinular columellae, sv sub-apical cavity, tc tectal columellae, te tectum. a, b bars $1 \mu \mathrm{m}$

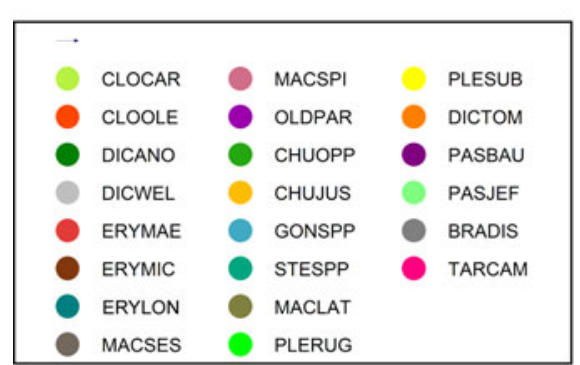

Fig. 5 PCA ordination diagram with the complete data-set showing specimen positions only. Traits and specimens are represented simultaneously in the PCA ordination diagram. In this diagram a few isolated groups were identified. BRADIS, Brachylaena discolor; CHUOPP, Chuquiraga oppositifolia; CHUJUS, C. jussieui; CLOCAR, Cloiselia carbonaria; CLOOLE, C. olaeifolia; DICANO, Dicoma anomala; DICTOM, D. tomentosa; DICWEL, "Dicomopsis"

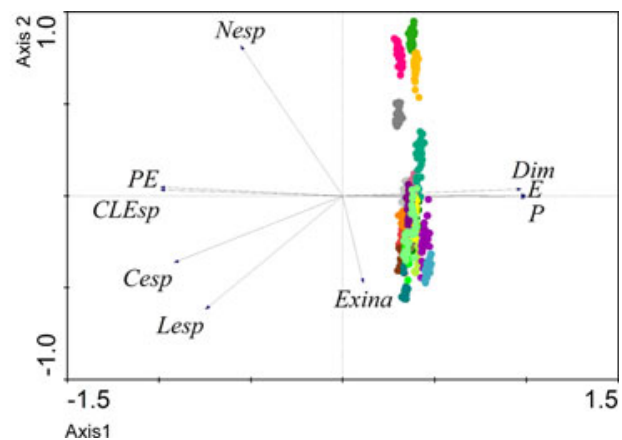

welwitschii; ERYLON, E. longifolium; ERYMAE, E. marginatum; ERYMIC, E. microcephalum; GONSPP, Gongylolepis sp.; MACLAT, Macledium latifolium; MACSES, M. sessiliflorum; MACSPI, M. spinosum; OLDPAR, Oldenburgia paradoxa; PASBAU, Pasaccardoa baumii; PASJEF, P. jeffreyi; PLERUG, Pleiotaxis rugosa; STESPP, Stenopadus sp.; TARCAM, Tarchonanthus camphoratus 
Pleiotaxis rugosa (incl. P.rugosa and P. subpaniculata)

Pollen grains oblate-spheroidal to prolate-spheroidal, $P / E=0.90-1.11(1.00 \pm 0.04)$, subcircular or elliptical in mos, triangular-circular or circular in eos $P=45.00$ $67.00(53.30 \pm 6.24) \mu \mathrm{m} ; E=44-68(53.00 \pm 6.60) \mu \mathrm{m}$. Mesoapertures lolongate (Fig. 1i, j), elliptic-shaped; endoapertures spindle-shaped, width of the endoapertures $=12.00-22.00(16.20 \pm 4.12) \mu \mathrm{m}$. Supporting columellae very variable in thickness and shape (Figs. 3h, $\mathrm{i}, 4 \mathrm{~b})$ some of them wide, more or less straight, ramified at the end, the others thin, loosely distributed and more or less curved, $1.10-2.10 \mu \mathrm{m} \times 0.16-1.50 \mu \mathrm{m}$, length/thickness $=1.50-10.00 ;$ exine thickness at the poles $=$ $6.20-11.00(8.30 \pm 1.10) \mu \mathrm{m}$. Spines with concave sides, attenuated or contracted to an acute or obtuse apex, length $=2.00-5.70(3.40 \pm 0.48) \mu \mathrm{m}$, width at the base $=$ $1.90-7.50(4.40 \pm 1.38) \mu \mathrm{m}$, length/width at the base $=$ $0.46-1.32(0.80 \pm 0.16)$, number of spines $/ 100 \mu \mathrm{m}^{2}$ in the mesocolpium $=1-4(2.50 \pm 0.83)$, inter-spinular sculpture microreticulate.

The following dichotomous key to Dicomeae pollen types is proposed:

1. Mesoapertures lalongate; supporting columellae thick, densely distributed and more or less straight; inter-spinular sculpture perforate or rugulateperforate.

.....Dicoma anomala (subtribe Dicominae)

- Mesoapertures lolongate; at least some of the supporting columellae thin, more or less loosely distributed and more or less curved; inter-spinular sculpture microreticulate (subtribe Pleiotaxinae)

2. Endoapertures spindle shaped, spines obtuse or acute, contracted or attenuated at the apex..................

Pleiotaxis rugosa

- Endoapertures "butterfly" shaped, spines acuminate, attenuated at the apex.

..Erythrocephalum longifolium

\section{Discussion}

The results we obtained for most of the pollen features (size, shape, apertures, sculpture) of the selected outgroups agree quite well with those reported by Parra and Marticorena (1972), Urtubey and Tellería (1998), Tellería (2008), and Ubiergo et al. (2009). The same is true for the general exine patterns described by Skvarla et al. (1977). In fact, the exines of Erythrocephalum marginatum, E. microcephalum (Ortiz and Pereira Coutinho 2001), E. longifolium, and Pleiotaxis rugosa have a typical anthemoid structural pattern (i.e. acaveate, with a thick foot layer, one layer of supporting columellae, several layers of outer columellae, and internal foramina absent). However, our results differ in some aspects from those reported by other authors.

For example, the dimensions we found for $P$ and $E$ and for the length of the spines are in general greater (1.1-1.6 times for $P$ and $E, 1.04-2.1$ for the length of the spines) than those reported by Hansen (1990) for the same species or genera. We believe, however, that these differences may arise because that author did not acetolyse the pollen grains he studied. We consider also the Dicoma general sculpture to be echinate and not areolate or verrucate (Perveen 1999).

The data published by the above mentioned authors, our own observations and PCA analysis (Fig. 5) revealed that the pollen grains of the studied species of tribes Oldenburgieae, Stifftieae, Tarchonantheae, and Wunderlichieae are all quite dissimilar from those of the Dicomeae. This is true (Table 3) of the values of $P$ and $E$ in Gongylolepis (Stifftieae) and Oldenburgia (Oldenburgieae) and of the number of spines in Chuquiraga (Barnadesieae), Brachylaena, and Tarchonanthus (Tarchonantheae). In fact, all are clearly larger than those of the Dicomeae (Table 1, Fig. 5). For these reasons, our results support the modern separation of the Dicomeae (Panero and Funk 2002) as an independent tribe.

The phylogenetic analysis of Panero and Funk (2008) using several cp DNA markers, and that of Ortiz et al. (2009) revealed that a clade comprising the Oldenburgieae and Tarchonantheae is the sister group of the Dicomeae. Our results give some support to this phylogenetic conclusion, because both tribes share a significative number of pollen characteristics with the Dicomeae (e.g. mesoapertures lolongate, similar to the Pleiotaxinae). It must be noted that the spine number and dimensions of the Oldenburgieae are clearly closer to the Dicomeae than those of the Tarchonantheae (Tables 1, 3, Fig. 5). Once again, these results agree with those cladograms, because the Oldenburgieae were placed in a closer position to the Dicomeae than the Tarchonantheae (Tables 2, 4, 5, 6).

Also, the palynological data undoubtedly support the division of the Dicomeae into two subtribes (Ortiz, unpublished). In fact, the mesoapertures are consistently lolongate in the Pleiotaxinae and lalongate in the Dicominae. In addition, at least some of the supporting columellae of the Pleiotaxinae are thinner, more curved and more loosely distributed (Figs. 3e, f, 4a, b) than those of the Dicominae (Figs. 1a, g, 2b, c, i). This is in agreement with micrographs of the exines of Erythrocephalum marginatum (SEM fractures and TEM) and Dicoma zeyheri (SEM 


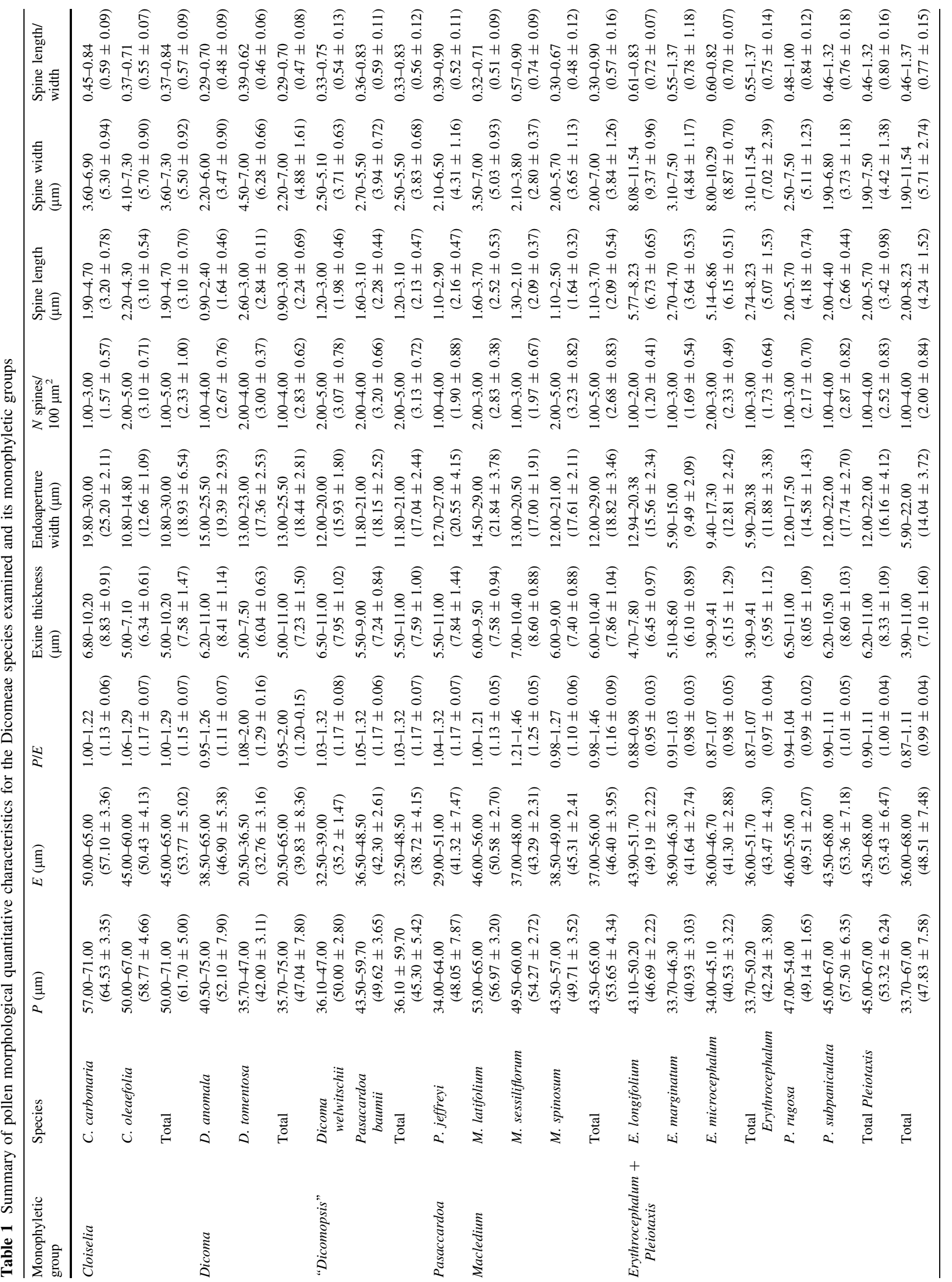




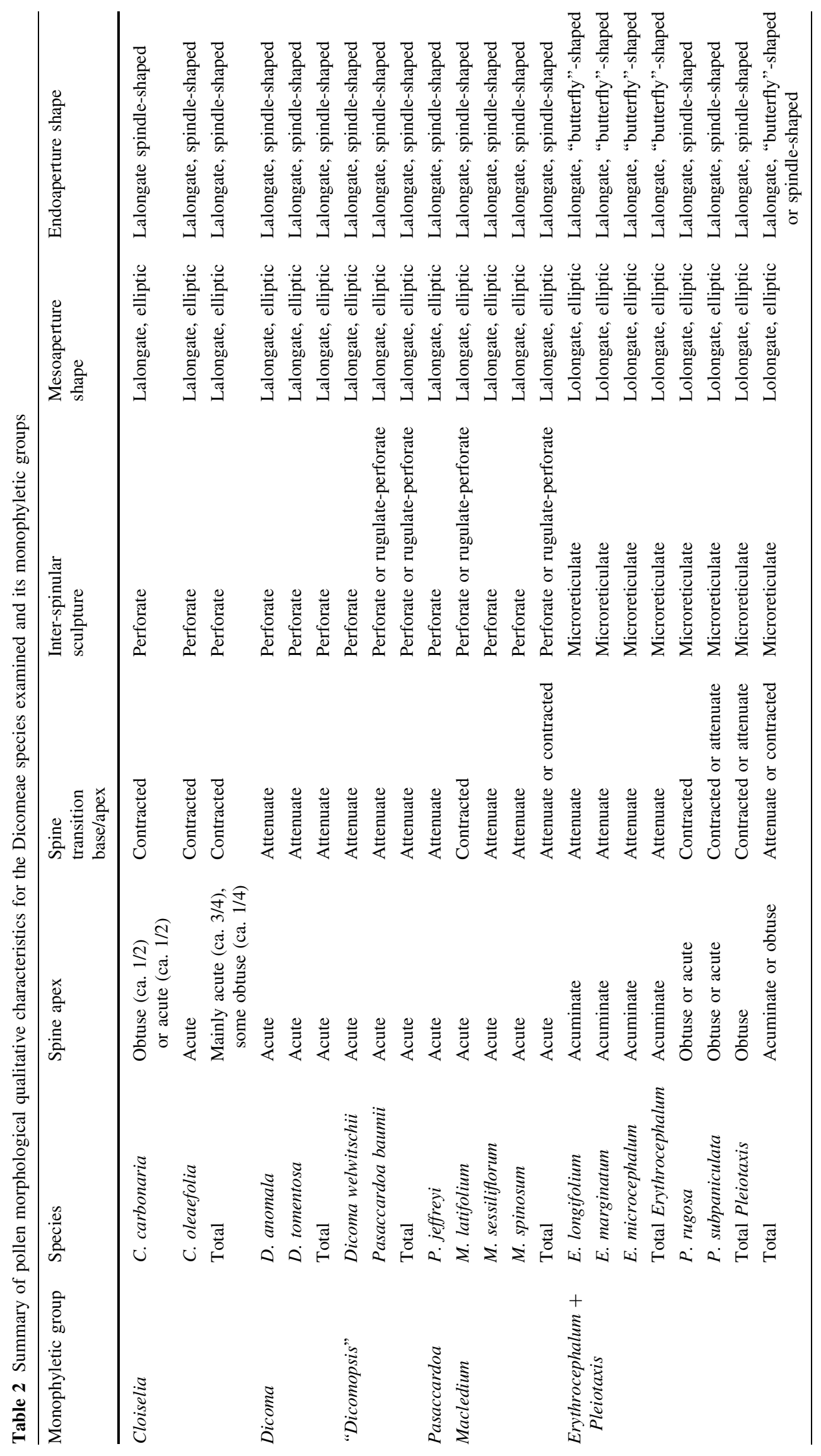




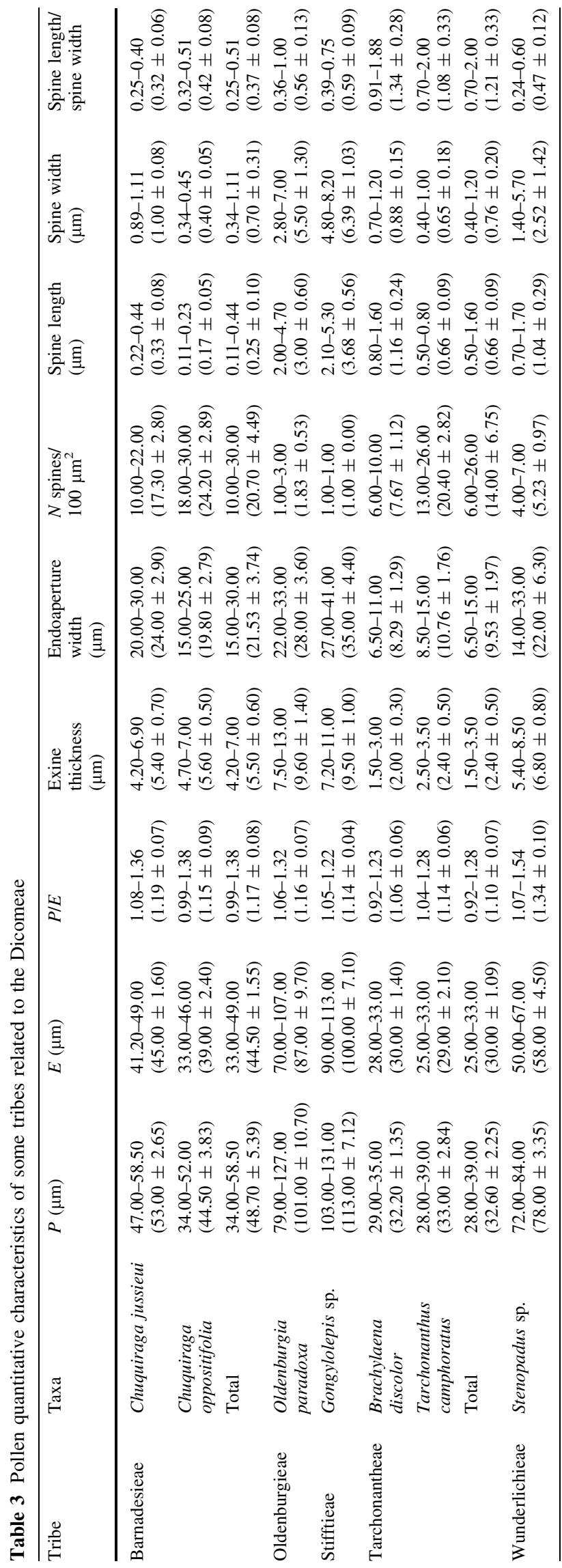

fractures) published by Blackmore et al.'s (2010) and with Stix's (1960) LM observations, this last author having pointed out the presence of supporting columellae of the thick, straight, and dense type in Dicoma and a thin, curved and spaced type in Erythrocephalum. In addition, the interspinular sculpture of the Pleiotaxinae is always microreticulate, and the inter-spinular sculpture of the Dicominae is predominantly perforate (these two kinds of ornamentation also agree with the SEM micrographs of Blackmore et al. 2010) or rarely rugulate-perforate. Moreover, the average and extreme values for the former subtribe of spine length and width and their ratio are, respectively, greater and smaller than those of the Dicominae (Table 1). The existence of two distinct mesoaperture shapes, sub-patterns of the anthemoid structure and patterns of sculpture in the Dicomeae could give some support to a hypothetical elevation of the Pleiotaxinae to the tribal rank (Ortiz et al. 2009). It is noteworthy that, although the qualitative data were not included, the PCA also revealed a trend for the separation of Dicominae and Pleiotaxinae (Fig. 6).

Although the existence of the Pleiotaxinae is well supported by the palynological data, it must be noted that the endoaperture and most of the spine shapes of the pollen grains of Pleiotaxis and Erythrocephalum are quite distinct, and the quantitative values of most of their characters differ substantially (Table 1). For those reasons we propose two distinct pollen types for the Pleiotaxinae we studied.

Interestingly, within the Dicominae, some of the Cloiselia palynological features are also somewhat distinct from those of all the other taxa we studied, and for several characters they represent an intermediate condition between the other Dicominae and the Pleiotaxinae. In fact, the Cloiselia pollen grains have maximum values of $P$ and $E$ larger than those of the other Dicominae (Table 1). In addition, the average spine dimensions (length and width at the base) for this genus are closer to the spine dimensions of the Pleiotaxinae (Table 1). Nevertheless, the existence of a continuous transition among the quantitative pollen characters of the Dicominae species we examined (Table 1) did not enable us to define two pollen types for this subtribe. On the contrary, we consider that our results support the existence of a large clade comprising the Macledium, Pasaccardoa, "Dicomopsis", Dicoma, and Cloiselia clades (Ortiz 2000; Ortiz et al. 2009), because the pollen grains of all these genera share important features, namely thick, more or less straight, dense supporting columellae, lalongate mesoapertures, and perforate (rarely rugulate-perforate) inter-spinular sculpture.

The average values we found for the equatorial diameter $(46.00 \mu \mathrm{m})$, the exine thickness $(7.50 \mu \mathrm{m})$, and the ratio "E/exine thickness" (6.13) of the Dicomeae are quite close to those indicated by Bolick (1991) for both the Mutisieae 
Table 4 Summary of pollen morphological qualitative characteristics for the Barnadesieae, Oldenburgieae, Stiffieae, Tarchonantheae, and Wunderlichieae species examined

\begin{tabular}{|c|c|c|c|c|c|c|}
\hline Tribe & Taxa & Spine apex & $\begin{array}{l}\text { Spine } \\
\text { transition } \\
\text { base/apex }\end{array}$ & $\begin{array}{l}\text { Inter- } \\
\text { spinular } \\
\text { sculpture }\end{array}$ & $\begin{array}{l}\text { Mesoaperture } \\
\text { shape }\end{array}$ & $\begin{array}{l}\text { Endoaperture } \\
\text { shape }\end{array}$ \\
\hline \multirow[t]{3}{*}{ Barnadesieae } & Chuquiraga jussieui & Acute & Attenuate & Psilate & Non-observable & Lalongate, spindle-shaped \\
\hline & $\begin{array}{l}\text { Chuquiraga } \\
\text { oppositifolia }\end{array}$ & Acute & Attenuate & Psilate & Non-observable & Lalongate, spindle-shaped \\
\hline & Total & Acute & Attenuate & Psilate & Non-observable & Lalongate, spindle-shaped \\
\hline Oldenburgieae & Oldenburgia paradoxa & Acute & Attenuate & Scabrate & Lolongate, elliptic & Lalongate, spindle-shaped \\
\hline Stifftieae & Gongylolepis sp. & Acute & Attenuate & Rugulate & Lalongate, elliptic & Lalongate, spindle-shaped \\
\hline \multirow[t]{3}{*}{ Tarchonantheae } & Brachylaena discolor & Acute & Attenuate & Scabrate & Lolongate, elliptic & Lalongate, spindle-shaped \\
\hline & $\begin{array}{c}\text { Tarchonanthus } \\
\text { camphoratus }\end{array}$ & $\begin{array}{l}\text { Acute (ca. } 4 / 5) \\
\text { or obtuse (ca. 1/5) }\end{array}$ & Attenuate & Scabrate & Non-observable & Lalongate, spindle-shaped \\
\hline & Total & $\begin{array}{l}\text { Mainly acute, } \\
\text { some obtuse }\end{array}$ & Attenuate & Scabrate & $\begin{array}{l}\text { Lolongate, elliptic, } \\
\text { or non-observable }\end{array}$ & Lalongate, spindle-shaped \\
\hline Wunderlichieae & Stenopadus sp. & Acute & Attenuate & Scabrate & Non-observable & Lalongate, spindle-shaped \\
\hline
\end{tabular}

Table 5 Eigenvalues and percentage of variance explained by the first three factors in principal-components analysis of the pollen data of the taxa of Dicomeae

\begin{tabular}{llll}
\hline Axis & Eigenvalue & $\%$ Variance & $\begin{array}{l}\text { Cumulative } \\
\text { variance }\end{array}$ \\
\hline 1 & 0.780 & 78.20 & 78.20 \\
2 & 0.098 & 9.80 & 88.00 \\
3 & 0.062 & 6.20 & 94.20 \\
\hline
\end{tabular}

Table 6 Eigenvalues and percentage of variance explained by the first three factors in principal-components analysis of the pollen data of the taxa of Dicomeae, Barnadesieae, Oldenburgieae, Stifftieae, and Tarchonantheae

\begin{tabular}{llll}
\hline Axis & Eigenvalue & $\%$ Variance & $\begin{array}{l}\text { Cumulative \% } \\
\text { variance }\end{array}$ \\
\hline 1 & 0.651 & 65.10 & 65.10 \\
2 & 0.241 & 24.10 & 89.20 \\
3 & 0.050 & 5.00 & 94.20 \\
\hline
\end{tabular}

(respectively: $43.10,6.50$, and $6.60 \mu \mathrm{m}$ ) and Cardueae (respectively: $49.10,6.50$, and $7.50 \mu \mathrm{m}$ ). Taking into account that the Mutisieae sensu lato included the Dicomeae, and that the Cardueae belong to a clade that includes also the Dicomeae (Funk et al. 2009; Ortiz et al. 2009), these similarities seem to be quite logical. Our results support that author's conclusion that pollen diameter and exine thickness in the Asteraceae are correlated with the exine ultrastructure type (anthemoid, in this case).

Some considerations about the palynoecology of the Dicomeae must be made. The existence in its exine of a tensile system of both outer and supporting columellae constitutes good protection against compressive forces (Bolick 1978, 1991). It must be pointed out that the thin supporting columellae of some Dicomeae (Pleiotaxinae, mainly Erythrocephalum) certainly enhance the efficiency of the harmomegathic mechanisms by increasing the flexibility of the exine (Muller 1979). Also, the presence of a multi-stratified (fragmented) internal tecta and the absence of internal foramina are effective defences against the loss of water by the male gametophyte, a clear ecological advantage in the xeric habitats where most of the species of Dicomeae live.

The main conclusions of this work can be summarized as follows:

1. All the taxa of Dicomeae share the same general pattern of structure (anthemoid);

2. the Dicominae and Pleiotaxine can be easily separated by their pollen morphology;

3. the hypothetical elevation of Pleiotaxinae to tribe status is supported by this study;

4. the pollen morphology of the taxa of Dicominae is quite similar, although Cloiselia is somewhat closer to the Pleiotaxinae than the other Dicominae;

5. within the Pleiotaxinae, the pollen grains of Erythrocephalum and Pleiotaxis share many important similarities, but also some significant differences;

6. within the tribes closely related to Dicomeae, the pollen morphology of the Oldemburgieae and Tarchonantheae (in this order) is closest to that of that tribe;

7. the pollen morphology of the related tribes Stifftiae, Oldenburgiae, Tarchonantheae, and Wunderlichieae is quite different from that of the Dicomeae. 
Fig. 6 Additional PCA was performed, removing isolated groups to identify others. Results from the PCA performed over the data-set restricted to Dicomeae is shown. CLOCAR, Cloiselia carbonaria; DICANO, Dicoma anomala; DICTOM, $D$. tomentosa; DICWEL,

"Dicomopsis" welwitschii; ERYMAR, Erythrocephalum marginatum; MACLAT, Macledium latifolium; PASBAU, Pasaccardoa baumii; PASJEF, P. jeffreyi; PLERUG, Pleiotaxis rugosa; PLESUB, Pleiotaxis subpaniculata

\begin{tabular}{|lll|}
\hline SAMPLES & & \\
CLOCAR & DICANO \\
DICWEL & ERYMAR \\
MACLAT & PLERUG \\
PLESUB & DICTOM \\
PASBAu & PASJEF \\
\hline
\end{tabular}

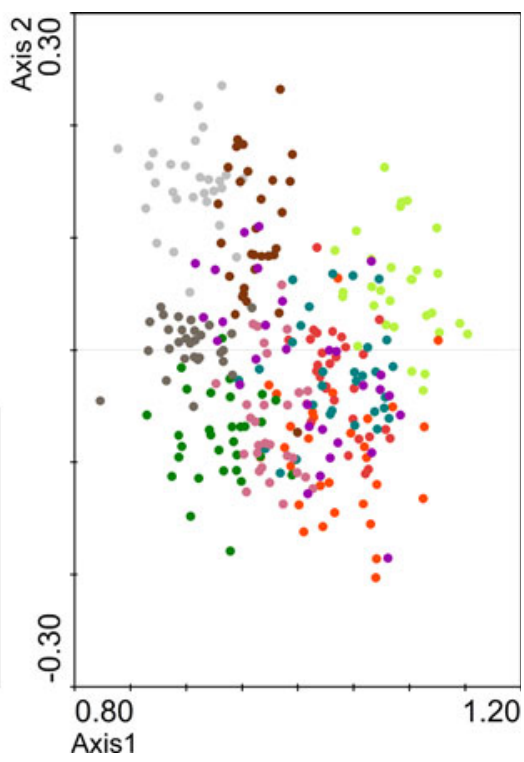

Acknowledgments The authors are grateful to the Directors of the COI, K, MA, NBG, PRE, and S herbaria for the loan of herbarium vouchers. The authors also thank Professor Augusto Dinis for allowing the use of equipment from the Laboratory of Microscopy, Department of Life Sciences (University of Coimbra), Professor Carlos Gonçalves, Director of the Laboratory of Histology of the Faculty of Medicine of the same University, for kindly helping us to obtain SEM micrographs of Pleiotaxis, and the anonymous reviewer.

\section{Appendix: Studied specimens}

Brachylaena discolor DC.

Moçambique. Ilha de Inhaca, 3.IX.1975, A. Reis Moura 695 (COI). Ilha de Inhaca, 27.VII1982, D. Zuzunga 357 (COI).

Chuquiraga jussieui J. F. Gmel.

Bolivia. LaPaz, Murillo, entre LaPaz y Palca, 25. II. 1979, A. Ceballos, Charpin, F. Casas \& V. Bermejo BO522 (MA).

Chuquiraga oppositifolia D. Don

Chile. Prov. Colchaqua, San Fernando, Termas del Flaco, 13. XI. 1983, G. Montero 12450 (MA).

Cloiselia carbonaria S. Moore

Madagascar. Vallées du Mangoky et de L' Isahaina, 10/1933, 11294 (K). La Table, Tuléar, 11. XI. 1962, F. Chauvet 359 (K). Plateau calcaire Mahafaly entre Stample et Ampanily, 16. X. 1970, M. Keraudren-Aymonin \& G. Aymonin 24572 (K).

Cloiselia oleifolia (Humbert) S. Ortiz

Madagascar. Collines des environs de Berlanyer, V. 1902, H. Bâthie 1428 (K). Environs de Tuléar, 6. XI. 1960, J. Leandri, Ratoto, Jean de Dieu 3730 (K).

Dicoma anomala Sond.

Zaire. Haut-Shaba, Plateau de la Monica. Angola. Huíla, Humpata, 9. VI. 1960, Teixeira \& Andrade 4740
(COI). Huambo, Nova Lisboa, Chianga, 6. VII. 1970, Silva 3181 (COI).

Dicoma tomentosa Cass.

Angola. Mossâmedes, 26. IV. 1938, Abreu 81 (COI). Mozambique. Tete, pr. Missão de Boroma, 21. VI. 1941, A. R. Torre 2921 (COI).

"Dicomopsis" welwitschii (= Dicoma welwitschii O. Hoffm.)

Angola. Benguela, Cacomba, 26. VII. 1905, Gossweiler 1798 (COI). Iter. Angolense, s. d., Welwitsch 3629 (COI). Quanza Sul, 24. VI. 1942, Excell \& Mendonça 3069 (COI). Huambo, Nova Lisboa, 15. VI, 1971, M. da Silva 3668 (COI).

Erythrocephalum longifolium Benth. ex Oliv.

Kenia. 8. I. 1969, Mouarig 114 (K). N'Gomeni, Tanga, 18. IV. 1964, H. Faackman, 3980 (K). Malawi. Musidi Road, 8. I. 1969, Mouarig 114 (K).

Erythrocephalum marginatum (O. Hoffm.) S. Ortiz \& A. P. Cout.

Tanzania. Dakara Ranch, 26. IV. 1988, Pócs 86 (K). Erythrocephalum microcephalum Dandy

Kenya. 35 miles SW of Kinui, 30. I. 1957, Bogdon 63 (K). Tanganyica. Kikori, 20. II. 1930, Burtt 64 (K). Uganda. I. 1922, Dummer 5015 (K).

Gongylolepis sp.

Venezuela. Territorio Federal del Amazonas, Depto. Atabapo, Cerro Duida, Rio Negro, 19. XI. 1991, J. Fuertes \& J. M. Cardiel 1267 (MA 524239)

Macledium latifolium (DC.) S. Ortiz

South Africa. Potberg, Bredasdorp, s. d., Acocks 23014 (PRE).

Macledium sessiliflorum (Harv.) S. Ortiz

Tanzania. Kilosa District, near Ruaha River, $12 \mathrm{~km} \mathrm{W.}$ of Kidatu Bridge, 4. IX. 1970, M. Thulin \& B. Mhoro 856 
(K). $26 \mathrm{~km} \mathrm{SE}$ of Mtware, $6 \mathrm{~km} \mathrm{SW}$ of Msimbati, 1. XI. 1977, R. Wingfield 4416 (K). Magubie, Mamboya, VIII. 1930, A. Haarer 1835 (K).

\section{Macledium spinosum (L.) S. Ortiz}

South Africa. Noukloof Nature Reserve, 13. XI. 1982,

D. F. Laidler 432 (PRE).

Oldenburgia paradoxa Less.

South Africa. Montagu, II.1983, Kotze \& Parker 341 (NBG). Western Cape Province, Oudtshoorn district, Cradockberg, George, IV. 1963, Esterhuysen 30160 (S).

\section{Pasaccardoa baumii O. Hoffm.}

Angola. Benguela, 1910, Gossweiler 3017 (K). Bié, Cuemba, 18. X. 1966, R. Monteiro \& Murta 2024 (COI). Bié, Chitembo, Anhara do Rio Cutato, a $7 \mathrm{~km}$ de Chuinda, 19. X. 1966, J. B. Teixeira et al. 10780 (COI).

\section{Pasaccardoa jeffreyi Wild}

Angola. Lunda, Xassengue, IV. 1937, H. W. (COI). Lunda, Xassengue, IV. 1937, Gossweiler 11799 (COI).

\section{Pleiotaxis rugosa $\mathrm{O}$. Hoffm.}

Angola. Lunda, Dala, 18. VIII. 1927, Carriço \& Mendonça 362 (COI). Huambo, 17. V. 1969, Moreno s. n. (COI). Huambo, pr. Rio Cuando, 17. V. 1969, Moreno, s. n. (COI).

\section{Pleiotaxis subpaniculata Chiov.}

Angola. Nova Lisboa, Sacaala, 18. II. 1962, Murta 103 (COI).

Stenopadus sp.

Venezuela. Territorio Federal del Amazonas, Depto. Atabapo, P. N. Duida-Marahuaca, Cerro Duida, Rio Negro, 19. XI. 1991, J. Pedrol 4585 JP (MA 524700).

Tarchonanthus camphoratus L.

Zimbabwe. Southern Zimbabwe, western slope of Dokodoko Mountain, 1 mile from Hot Springs, 23 X. 1948, N. C. Chase 921 (COI).

\section{References}

Blackmore S, Wortley AH, Skvarla JJ, Robinson H (2009) Evolution of pollen in compositae. In: Funk VA, Susanna A, Stuessy TF, Bayer RJ (eds) Systematics, evolution, and biogeography of compositae. Sheridan Books Inc, Ann Arbor, Michigan, pp 101-130

Blackmore S, Wortley AH, Skvarla JJ, Gabarayeva AH, Rowley JR (2010) Developmental origins of structural diversity in pollen walls of compositae. Plant Syst Evol 284:17-32

Bolick M (1978) Taxonomic, evolutionary and functional considerations of compositae pollen ultrastructure and sculpture. Plant Syst Evol 130:209-218

Bolick M (1991) Pollen diameter, exine thickness, and ultrastructure type in the tribes of the compositae. Comp News 19:17-21

Bremer K (1994) Asteraceae. Cladistics and classification. Timber Press, Portland

Cabrera AL (1977) Mutisieae-systematic review. In: Heywood VH, Harborne JB, Turner BL (eds) The biology and chemistry of the compositae, vol 2. Academic Press, London, pp 1039-1066
Erdtman G (1960) The acetolysis method. Svensk Bot Tidskr 54:561-564

Funk V, Susanna A, Stuessy TF, Bayer RJ (2009) Systematics, evolution and biogeography of compositae. Sheridan Books Inc, Ann Arbor

Hansen HV (1990) SEM-studies and general comments on pollen in tribe Mutisieae (compositae) sensu Cabrera. Nord J Bot 10:607-623

Hesse M, Halbritter H, Zetter R, Weber M, Buchner R, Frosh-Radivo A, Ulrich S (2009) Pollen terminology—an illustrated handbook. Springer, Wien, New York

Hoffmann O (1890) Compositae. In: Engler A, Prantl K (eds) Die Natürlichen Pflanzenfamilien, vol 4., 5Engelmann, Leipzig, pp 87-391

Jeffrey C (1967) Notes on compositae, II. The Mutisieae in East Tropical Africa. Kew Bull 21:177-223

Legendre P, Legendre L (1998) Numerical ecology 2nd English edition. Elsevier Science BV, Amsterdam

Muller J (1979) Form and function in Angiosperm pollen. Ann Missouri Bot Gard 66:593-632

Ortiz S (2000) A phylogenetic analysis of Dicoma Cass. and related genera (Asteraceae: Cichorioideae: Mutisieae) based on morphological and anatomic characters. Ann Missouri Bot Gard 87:459-481

Ortiz S, Pereira Coutinho A (2001) Achyrothalamus reduced to Erythrocephalum (Asteraceae, Mutisieae). Taxon 50:389-403

Ortiz S, Carbajal R, Serrano M, Coutinho AP (2009) Dicomeae (Carduoideae). In: Funk VA, Susanna A, Stuessy TF, Bayer RJ (eds) Systematics, evolution, and biogeography of compositae. Sheridan Books Inc, Ann Arbor, Michigan, pp 267-278

Panero JL, Funk VA (2002) Toward a phylogenetic sub familial classification for the compositae (Asteraceae). Proc Biol Soc Wash 115:909-922

Panero JL, Funk VA (2008) The value of sampling anomalous genera in phylogenetic studies: major clades of the Asteraceae revealed. Mol Phylogenet Evol 47:757-782

Parra O, Marticorena C (1972) Granos de polen de plantas chilenas. II. Compositae-Mutisieae. Gayana 21:3-107

Pereira Coutinho A, Dinis AM (2007) A contribution to the ultrastructural knowledge of the pollen exine in subtribe Inulinae (Inuleae, Asteraceae). Plant Syst Evol 269:159-170

Perveen A (1999) Contributions to the Pollen morphology of the family compositae. Tr J of Biology 23:523-535

Punt W, Hoen PP, Blackmore S, Nilsson S, Le Thomas A (2007) Glossary of pollen and spore terminology. Rev Palaeobot Palynol 143:1-81

Skvarla JJ, Larson D (1965) An electron microscopic study of pollen morphology in compositae with special reference to the Ambrosiinae. Grana Palynol 6(2):210-267

Skvarla JJ, Turner BL, Patel VC, Tomb AS (1977) Pollen morphology in the compositae and in morphologically related families. In: Heywood VH, Harborne JB, Turner BL (eds) The biology and chemistry of compositae. Academic, London, pp 141-265

Skvarla JJ, DeVore ML, Chissoe WF (2005) Lophate sculpture of Vernonieae (compositae) pollen. Rev Palaeobot Palynol 133: $51-68$

Stix E (1960) Pollenmorphologische Untersuchungen an Compositen. Grana Palynol 2(2):41-114

Tellería MC (2008) Taxonomic significance of pollen types in the Guayana highland-centred composite genera of Mutisioideae (Asteraceae). Bot J Linn Soc 156:327-340

Tellería MC, Katinas L (2005) The unusual occurrence of tricolpate pollen within Mutisieae (Asteraceae). Grana 44:91-97

Ubiergo P, Lapp M, Torrecilla P (2009) Morfología del polen de especies de Gongylolepis (Mutisieae: Asteraceae) de la Guayana venezolana. Anales Jard Bot Madrid 66(1):93-107 
Urtubey E, Tellería MC (1998) Pollen morphology of the subfamily Barnadesioideae (Asteraceae) and its phylogenetic and taxonomic significance. Rev Palaeobot Palynol 104:19-37

Wodehouse RP (1929) Pollen grains in the identification and classification of plants. IV. The Mutisieae. Am J Bot 16:297-313
Wortley AH, Funk VA, Skvarla JJ (2008) Pollen and the evolution of Arctotideae (compositae). Bot Rev 74:438-466

Zavada M, De Villiers S (2000) Pollen of the Asteraceae from the Paleocene-Eocene of South Africa. Grana 39:39-45 